\title{
DPP 4 (dipeptidylpeptidase-4) inhibitors: beyond glycemic control
}

\author{
Sunil kumar gothwal ${ }^{1}$, Surendra khosya ${ }^{2}$ \\ ${ }^{1}$ Assistant professor, general medicine, m.a.m.c., agroha, hisar \\ ${ }^{2}$ Assistant professor, general medicine, m.a.m.c., agroha, hisar
}

\begin{abstract}
Type 2 diabetes is characterized by impaired insulin release from $\beta$-cell of pancreas and insulin resistance. Different classes of hypoglycemic drugs are available with different mechanism of action with nearly equipotent efficacy. GLP-1(glucagon like peptide-1) analogue and DPP 4 inhibitors are new developed molecules for the management of diabetes. They act via glucose dependent insulin release from $\beta$-cells as physiological manner. Here in this review we will discuss about the adventitous systemic effects of incretins and DPP 4 inhibitors beyond glycemic control.
\end{abstract}

Key words: DPP 4 inhibitors; GLP 1 analogues; incretins

\section{INTRODUCTION}

DPP 4 (dipeptidyl peptidase-4) inhibitors are the recently developed and approved chemical for the treatment of the diabetes mellitus. They act mainly on pancreas via inhibition of degradation of the incretin hormones such as type 1 glucagon like peptide (GLP-1), and GIP. The Incretin hormones are release from the intestine in response to oral glucose ingestion and stimulate insulin release from $\beta$-cells of pancreas (so called incretin effect), and also suppress glucagon release from $\alpha$-cells of pancreas. DPP-4 inhibitors are approved for the treatment in Type 2 diabetes either as monotherapy or as add-on therapy with other oral hypoglycemic agents like metformin. There are numerous DPP4 inhibitors; some are in various stages of clinical development. The first approved DPP4 was sitagliptin in 2006. Then vildagliptin, saxagliptin, alogliptine, linagliptine, anagliptin and teneligliptin were introduced.

Table- Different DPP4 inhibitors with their pharmacokinetics

\begin{tabular}{|c|c|c|c|c|c|}
\hline Drug & Sitagliptin & Vildagliptin & Linagliptin & saxagliptin & Alogliptin \\
\hline blockade & competitive & $\begin{array}{l}\text { Substrate } \\
\text { blocker }\end{array}$ & competitive & competitive & Competitive \\
\hline Dose(mg) & $1 \times 100 /$ day & $2 \times 50 /$ day & $1 \times 5 /$ day & $1 \times 5 /$ day & $\begin{array}{l}1 \times 12.5- \\
25 / \text { day }\end{array}$ \\
\hline Excretion & $\begin{array}{l}80 \% \\
\text { unchanged } \\
\text { in urine }\end{array}$ & $\begin{array}{l}\text { Via urine, } 21 \% \\
\text { unchanged }\end{array}$ & $\begin{array}{l}84 \% \\
\text { unchanged } \\
\text { via faces, } \\
<6 \% \text { urine }\end{array}$ & $12-51 \%$ via urine & $\begin{array}{l}60-71 \% \text { via } \\
\text { urine, } \\
\text { unchanged }\end{array}$ \\
\hline Metabolism & Low & Liver & Low & Liver & Low \\
\hline $\begin{array}{l}\text { Renal } \\
\text { insufficiency }\end{array}$ & $\begin{array}{l}\text { Dose } \\
\text { adjustment }\end{array}$ & $\begin{array}{l}\text { Not } \\
\text { recommended }\end{array}$ & $\begin{array}{l}\text { No dose } \\
\text { adjustment }\end{array}$ & Dose adjustment & $\begin{array}{l}\text { Dose } \\
\text { adjustment }\end{array}$ \\
\hline $\begin{array}{l}\text { Hepatic } \\
\text { insufficiency }\end{array}$ & $\begin{array}{l}\text { No dose } \\
\text { adjustment }\end{array}$ & $\begin{array}{l}\text { No dose } \\
\text { adjustment but } \\
\text { liver testing } \\
\text { before } \\
\text { administration }\end{array}$ & $\begin{array}{l}\text { No dose } \\
\text { adjustment }\end{array}$ & $\begin{array}{l}\text { Dose adjustment in co- } \\
\text { administration with } \\
\text { CYP- } \\
\text { enhancer/suppressors }\end{array}$ & $\begin{array}{l}\text { No dose } \\
\text { adjustment }\end{array}$ \\
\hline
\end{tabular}

\section{Glycemic control}

After meal, GLP-1 and GIP are secreted from the small intestine, but they are rapidly degraded by the enzyme DPP-4. Inhibition of DPP-4 prevents the degradation of GLP-1 and GIP and enhances glucosestimulated insulin secretion (incretin action). GLP-1 and GIP act on the pancreatic $\beta$-cell to increase insulin release. GLP-1 also acts on the $\alpha$-cell to suppress glucagon release and ultimately suppress hepatic glucose production. Together, the increased cellular glucose uptake and the decreased hepatic glucose output offer physiologic glucose control. 


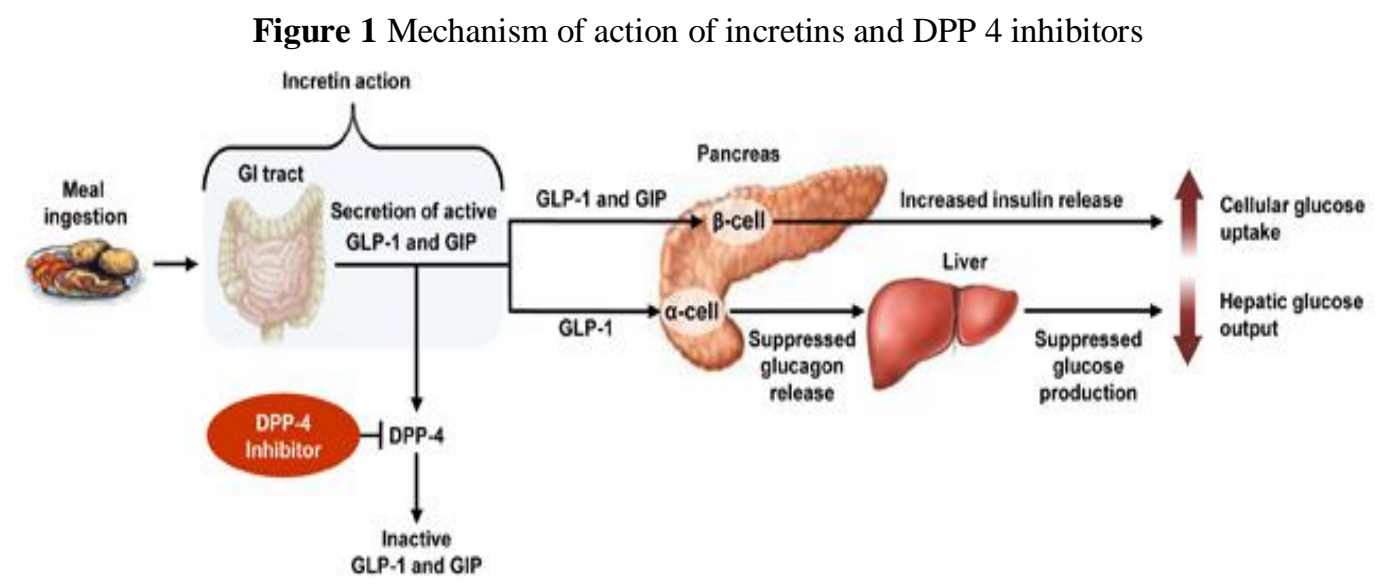

\section{Beyond glycemic control}

The growing incidence of type 2 diabetes mellitus (T2DM) leads to global public health crisis. The secondary complications associated with diabetes are frequent, severe, progressive and costly ${ }^{[1-3]}$ cause significant burden of morbidity and mortality. They include diabetic nephropathy, coronary heart disease, stroke, peripheral arterial disease, neuropathy, as well as retinopathy. Despite reduction in the HbA1c the oral hypoglycemic drugs have little effect in term of protection from end organ damage. Although the safety profile of the recently introduced dipeptidyl peptidase-4 inhibitors(DPP-4 inhibitors) drugs has yet to be formally assessed, there is anticipation that they will offer benefits over existing therapies for example they don't cause fluid and water retention as with peroxisome proliferator-activated receptor (PPAR) alpha/gamma agonists.

GLP-1 receprtors are mainly expressed in the $\beta$-cells of pancreas. GLP-1 receptors are also expressed in various tissues like heart, kidney, CNS, lung, vascular endothelium, g.i. tract etc. Thus DPP 4 inhibitors also exert some effect on these systems.

\section{Effects on Islet -cell Function}

Type 2 diabetes is a progressive disease. As the UKPDS study demonstrate that b-cell function which was already loss up to $50 \%$ at the time of diagnosis ${ }^{(4)}$, keep declining as the disease progress with worsening of glycemic control. Recent data from human autopsy studies confirm that $\beta$-cell mass is decreased in patients with type 2 diabetes ${ }^{(5)}$.The main etiology behind this is increase $\beta$-cell apoptosis.

In clinical studies it was found that both incretins and DDP4 inhibitors shown to improve $\beta$-cell function. The effects of DPP-4 inhibition on $\beta$-cell function were studied by Xu and associates ${ }^{(6)}$, who assessed the effect of sitagliptin on pancreatic $\beta$-cell function. They found that when sitagliptin is administered as in combination with metformin or as monotherapy, sitagliptin was not only associated with substantial reductions in postprandial glycemic excursions but also produced significant improvements in the static insulin resistence (ISR) and the average ISR over the average glucose concentrations. They concluded that sitagliptin improved bcell function relative to placebo in both fasting and postprandial states in patients with type 2 diabetes. A similar study was done by Mari and associates ${ }^{(7)}$ with vildagliptin, they found tha vildagliptin improves b-cell function in patients with diabetes by increasing the insulin secretory tone. Chang and colleagues ${ }^{(8)}$ did a study with liraglutde and found that, In subjects with type 2 diabetes, liraglutide, in comparison with placebo, significantly increased insulin and C-peptide levels, the ISR area under the curve, and the slope of ISR versus plasma glucose, with values similar to those of nondiabetic control subjects. Thus liraglutide restored $\beta$-cell responsiveness to physiologic hyperglycemia in subjects with type 2 diabetes ${ }^{(8)}$.

\section{EFFECTS ON INSULIN SENSITIVITY}

Type 2 diabetes characterized by impaired insulin secretion as well as by decrease insulin sensitivity. GLP-1 analogues associated with increased insulin action as well as sensitivity.

\section{Effect on appetite, food intake and gastric emptying}

It is well known that incretins and DPP4 inhibitors act via stimulating glucose-dependent insulin secretion and suppressing postprandial glucagon secretion. However, some of their glycemic effects may also be mediated through their effects on gastric emptying, satiety, and food intake. Several studies have demonstrated that peripheral infusions of GLP-1 significantly enhance satiety and decrease food intake in lean healthy volunteers and obese nondiabetic and diabetic subjects ${ }^{(9-11)}$. 


\section{CARDIOVASCULAR PROTECTION}

\section{Effect on Myocardial function}

Heart failure, myocardial infarction, cardiac hypertrophy and coronary artery disease is often associated with diabetes and metabolic syndrome. As the DPP-4 enzyme is involved not only in the regulation of glucose but also several substrates (like BNP,brain natriuretic peptide; SDF-1, type 1 stromal derived factor; NPY, neuropeptide; PYY, peptide YY) known to have cardiovascular, renal and immune-modulating actions. Thus long-term DPP-4 inhibition may have clinical benefits and/or consequences including cardioprotective actions. Effects on contractility, blood pressure, cardiac output and cardioprotection appear to be independent of diabetes ${ }^{[12-19]}$. A few studies have been published on cardioprotective effect of GLP-1 analogues and DPP 4 inhibitors. In studies done on mice genetically lacking the DPP-4 receptors that were treated with sitagliptin, the investigators induced acute myocardial infarction by left anterior descending coronary artery ligation ${ }^{(20)}$. In these mice, an upregulation of cardio-protective genes and their protein products was shown. In another study in mice, it was shown that treatment with sitagliptin can reduce the infarct area and the protective effect of sitagliptin was protein kinase A dependent ${ }^{(21)}$. In diabetic patients who suffer from ischemic heart disease, it was demonstrated that treatment with sitagliptin improved their heart function and coronary artery perfusion, as observed in echodebutamin tests ${ }^{(22)}$.

\section{EFFECT ON BLOOD PRESSURE}

The effect of DPP 4 inhibitors on blood pressure is contradictory. In diabetic rats, sitagliptin was associated with a significant normalization of blood pressure in diabetic rats with elevated blood pressure (versus non-diabetic rats) ${ }^{(23)}$, whereas vildagliptin showed no influence on blood pressure in hypertensive fatty rats ${ }^{(24)}$. Recently, a study by Marney et al. ${ }^{(25)}$, in metabolic syndrome patients, showed that during placebo and low-dose ACE inhibition (5 mg enalapril), sitagliptin lowered blood pressure. However, this trend was reversed during higher-dose acute ACE inhibition (10 mg enalapril). They hypothesized that the combination of sitagliptin and high-dose ACE inhibition causes activation of the sympathetic tone, hence attenuating blood pressure reduction. Marney et al. suggested that high levels of substance $\mathrm{P}$, because of the double blockade of ACE and DPP-4, caused the activation of the sympathetic system.

\section{ENDOTHELIAL FUNCTION}

Endothelia dysfunction is an independent predictor for cardiovascular events in patients with type 2 diabetes. In some studies it was found that GLP-1 has some vasodilatory action and Sitagliptin significantly improved endothelial function and inflammatory state in patients with coronary artery disease and uncontrolled diabetes mellitus.

\section{LIPID METABOLISM}

DPP 4 inhibitors found to decrease the postprandial surge in lipid levels. Matikainen et al. ${ }^{(26)}$ in his study found that treatment with vildagliptin for 4 weeks improves postprandial plasma triglyceride and apolipoprotein B-48-containing triglyceride-rich lipoprotein particle metabolism after a fat-rich meal in drugnaive patients with type 2diabetes. Hsieh et al. ${ }^{(27)}$ also suggested that DPP 4 inhibitors augment the level of GLP-1receptors thus reduce secretion of tryglycerol, cholesterol, and apolipoprotein B-40 from intestine. Antiatherosclerotic effect has been found in some model by reducing media-intima ratio in carotid artery of rat in dose dependent manner.

\section{RENAL PROTECTION}

Diabetes is the one of the most common cause of end stage renal disease (ESRD). And in patient with diabetes; hypertention and hyperglycemia are the major risk factor for the development of the ESRD. Thus slowing of progression and attenuation can be achieved by intensive effort to control hypertention and hyperglycemia. GLP-I reduce the glomerular hyperfiltration and it is diuretic and natriuretic in obese insulin resistant subjects. In one experimental model it was found that co-administration of linagliptin and the telmisartan, after only 11 weeks of treatment was associated with a marked reduction in albuminuria, an early predictor of diabetic nephropathy and cardiovascular morbidity ${ }^{(28)}$. Both plasma osteopontin (a marker of vascular calcification and fibrosis) and glomerulosclerosis (an indicator of morphologic changes in diabetic nephropathy) were significantly lower in linagliptin-treated subjects. Changes that could similarly be considered to be of potential clinical benefit were observed in proteinuria, albuminuria, urinary albumin/creatinine ratio, creatinine clearance, interstitial volume, glomerulosclerosis and glomerular basement membrane thickness. These effects appeared to be independent of blood glucose. Inhibitors of the DPP-4 enzyme have been shown to have a very good overall safety and tolerability profile, but for those excreted via the kidney dose adjustment is needed to avoid drug accumulation in patients with renal impairment. Linagliptin 
is currently the only DPP-4 inhibitor that is not excreted via the kidney and does not need dose adjustment at any degree of declining kidney function.

\section{NEURO-PROTECTION}

It is well known that GLP-1 is not solely a gastrointestinal hormone and that it also has actions in other tissues including the central nervous system. In humans, in vitro GLP-1 receptor autoradiography ${ }^{(29)}$ has revealed that the brain GLP-1 receptor mRNA is widely distributed throughout the cerebral cortex, hypothalamus (mainly ventromedial and arcuate nuclei), hippocampus, thalamus, caudate- putamen, and globus pallidum. In another study in humans, the most striking receptor expression was observed in the neurohypophysis, where the highest GLP-1 receptor density of all tissues was measured. ${ }^{\left({ }^{30)}\right.}$ There is growing evidence that the ability of GLP-1 and the incretin hormones to affect gastric emptying, satiety, and food intake is mediated centrally. Inhibition of gastric emptying by GLP-1 is mediated by vagal afferents and leads to gastric distension ${ }^{(31)}$. This in turn leads to further activation of vagal afferents and signals from the stomach to the brain, which leads to a perception of fullness and satiety. ${ }^{(32)}$

Since GLP-1 and the GLP-1 receptor are expressed in most parts of the brain, it would be expected that GLP-1 agonism might have beneficial effects on brain physiology and function. This has been borne out in animal studies where centrally administrated GLP-1 has been shown to improve learning behavior and provide neuroprotection against toxin-induced apoptosis and seizures. ${ }^{(33,34)}$ These effects raise the exciting possibility that GLP-1 and its analog could prove to be novel therapeutic agents for use in enhancing cognition and delaying/preventing degeneration in neurodegenerative diseases like Parkinson's disease and alzeimer disease.

\section{CONCLUSION}

The incretin agents (GLP-1 receptor agonists and the DPP-4 inhibitors) belong to a unique class of antidiabetic agents. These agents have pleiotropic effects that extend beyond their known ability to lower glucose. These include effects to improve b-cell function and mediation of trophic effects on the b-cell (in animal and in vitro models); effects to reduce postprandial lipemia; effects to lower blood pressure; effects to improve myocardial contractility and endothelial function; and potential neuroprotective, neurotrophic, and bone resorptive effects (seen only in animal models). These beneficial effects of the incretins (if confirmed in longterm studies) have the potential to favorably influence the course of the disease process and its complications in patients with type 2 diabetes.

\section{REFERENCES}

[1]. Anon.: CDC - 2005 National Diabetes Fact Sheet - Publications - Diabetes DDT

[2]. King H, Aubert RE, Herman WH: Global burden of diabetes, 1995-2025: prevalence, numerical estimates,and projections, Diabetes Care 1998; 21:1414-1431.

[3]. Rodbard HW, Blonde L, Braithwaite SS, Brett EM, Cobin RH, Handelsman Y, Hellman R, Jellinger PS, Jovanovic LG, Levy P, Mechanick JI, Zangeneh F: American Association of Clinical Endocrinologists medical guidelines for clinical practice for the management of diabetes mellitus. Endocr Pract 2007; 1

[4]. UK Prospective Diabetes Study Group. UK Prospective Diabetes Study 16: overview of 6years' therapy of type II diabetes-A progressive disease. Diabetes $1995 ; 44: 1249-1258$

[5]. Butler AE, Janson J, Bonner-Weir S, Ritzel R, Rizza RA, Butler PC. Beta-cell deficit and increased beta cell apoptosis in humans with type 2 diabetes. Diabetes 2003; 52:102-110.

[6]. Xu L, Man CD, Charbonnel B, et al. Effect of sitagliptin, a dipeptidyl peptidase-4 inhibitor, on beta-cell function in patients with type 2 diabetes: a model-based approach Diabetes Obes Metab 2008; 10: 1212-1220.

[7]. Mari A, Sallas WM, He YL, et al. Vildagliptin, a dipeptidyl peptidase- IV inhibitor, improves model-assessed beta-cell function in patients with type 2 diabetes J Clin Endocrinol Metab 2005; 90:4888-4894.

[8]. Chang AM, Jakobsen G, Sturis J, et al. The GLP-1 derivative NN2211 restores beta-cell sensitivity to glucose in type 2 diabetic patients after a single dose. Diabetes 2003; 52:1786-1791.

[9]. Flint A, Raben A, Astrup A, Holst JJ. Glucagon-like peptide 1 promotes satiety and suppresses energy intake in humans. J Clin Invest. 1998; 101: 515-520.

[10]. Naslund E, Barkeling B, King N, et al. Energy intake and appetite are suppressed by glucagon-like peptide-1 (GLP-1) in obese men. Int J Obes Relat Metab Disord.1999; 23:304-311.

[11]. Gutzwiller JP, Drewe J, Goke B, et al. Glucagon-like peptide-1 promotes satiety and reduces food intake in patients with diabetes mellitus type 2. Am J Physiol Regul Integr Comp Physiol. 1999; 276: R1541- R1544.

[12]. Huisamen B, Genade S, Lochner A: Signalling pathways activated by glucagon-like peptide-1 (7-36) amide in the rat heart and their role in protection against ischaemia. Cardiovasc J Afr 2008; 19:77-83.

[13]. Huisamen B, Genis A, Marais E, Lochner A: Pre-treatment with a DPP-4 inhibitor is infarct sparing in hearts from obese, prediabetic rats. Cardiovasc Drugs Ther 2011; 25:13-20.

[14]. Gardiner SM, March JE, Kemp PA, Bennett T, Baker DJ: Possible involvement of GLP-1(9-36) in the regional haemodynamic effects of GLP-1(7-36) in conscious rats. Br J Pharmacol 2010; 161:92-102.

[15]. Sokos GG, Nikolaidis LA, Mankad S, Elahi D, Shannon RP: Glucagon-like peptide-1 infusion improves left ventricular ejection fraction and functional status in patients with chronic heart failure. J Card Fail 2006; 12:694-699.

[16]. Nikolaidis LA, Doverspike A, Hentosz T, Zourelias L, Shen Y-T, Elahi D, Shannon RP: Glucagon-like peptide- 1 limits myocardial stunning following brief coronary occlusion and reperfusion in conscious canines. J Pharmacol Exp Ther 2005; 312:303-308. 
[17]. Nikolaidis LA, Elahi D, Hentosz T, Doverspike A, Huerbin R, Zourelias L, Stolarski C, Shen Y, Shannon RP: Recombinant glucagon-like peptide-1 increases myocardial glucose uptake and improves left ventricular performance in conscious dogs with pacing-induced dilated cardiomyopathy. Circulation 2004; 110:955-961.

[18]. Nikolaidis LA, Mankad S, Sokos GG, Miske G, Shah A, Elahi D, Shannon RP: Effects of glucagon-like peptide-1 in patients with acute myocardial infarction and left ventricular dysfunction after successful reperfusion. Circulation 2004; 109:962-965.

[19]. Bose AK, Mocanu MM, Carr RD, Brand CL, Yellon DM: Glucagon-like peptide 1 can directly protect the heart against ischemia/reperfusion injury. Diabetes 2005; 54:146-151.3:S1-68.

[20]. Sauvé M, Ban K, Momen MA, et al. Genetic deletion or pharmacological inhibition

[21]. of dipeptidyl peptidase-4 improvescardiovascular outcomes after myocardial infarction in mice. Diabetes 2010; 59: 1063-1073

[22]. Ye Y, Keyes KT, Zhang C, Perez-Polo JR,Lin Y, BirnbaumY. The myocardial infarct size-limiting effect of sitagliptin is PKAdependent, whereas the protective effect of pioglitazone is partially dependent on PKA. Am J Physiol Heart Circ Physiol 2010; 298:H1454-H1465

[23]. Read PA, Khan FZ, Heck PM, Hoole SP, Dutka DP. DPP-4 inhibition by sitagliptin improves the myocardial response to dobutamine stress and mitigates stunning in a pilot study of patients with coronary artery disease. Circ Cardiovasc Imaging 2010; 3:195-201

[24]. Ferreira L, Teixeira-de-Lemos E, Pinto F, Parada B, Mega C, Vala H, Pinto R, Garrido P, Sereno J, Fernandes R, Santos P, Velada I, Melo A, Nunes S, Teixeira F, Reis F: Effects of sitagliptin treatment on dysmetabolism, inflammation, and oxidative stress in an animal model of type 2 diabetes (ZDF rat). Mediators Inflamm 2010; 2010:592760.

[25]. Matsui T, Nishino Y, Takeuchi M, Yamagishi S: Vildagliptin blocks vascular injury in thoracic aorta of diabetic rats by suppressing advanced glycation end product-receptor axis. Pharmacol Res.2011; 63: 383-388.

[26]. Marney A, Kunchakarra S, Byrne L, Brown NJ.Interactive hemodynamic effects of dipeptidyl peptidase-IV inhibition and angiotensin-converting enzyme inhibition in humans. Hypertension 2010; 56:728-733

[27]. Matikainen N, Mänttäri S, Schweizer A, et al. Vildagliptin therapy reduces postprandial intestinal triglyceride-rich lipoprotein particles in patients with type 2 diabetes.Diabetologia2006; 49:2049-2057

[28]. Hsieh J, Longuet C, Baker CL, et al. The glucagon-like peptide 1 receptor is essential for postprandial lipoprotein synthesis and secretion in hamsters and mice. Diabetologia2010; 53:552-561.

[29]. Alter M, Ott I, von Websky K, Tsuprykov O, Sharkovska Y, Krause-Relle K, Raila J, Henze A, Klein T, Hocher B: DPP-4 inhibition on top of angiotensin receptor blockade offers a new therapeutic approach for diabetic nephropathy. Kidney Blood Press Res DOI: 10.1159/000341487.

[30]. Alvarez E, Martinez MD, Roncero I, et al. The expression of GLP-1 receptor mRNA and protein allows the effect of GLP-1 on glucose metabolism in the human hypothalamus and brainstem. J Neurochem 2005; 92: 798-806.

[31]. Körner M, Stöckli M, Waser B, Reubi JC. GLP-1 receptor expression in human tumors and human normal tissues: potential for in vivo targeting. J Nucl Med 2007; 48: 736-743.

[32]. Imeryüz N, Yeg en BC, Bozkurt A, Cos,kun T, Villanueva-Peñacarrillo ML, Ulusoy NB. Glucagon-like peptide-1 inhibits gastric emptying via vagal afferent-mediated central mechanisms. Am J Physiol. 1997; 273(pt 1):G920-G927.

[33]. Wang GJ, Tomasi D, Backus W, et al. Gastric distention activates satiety circuitry in the human brain. Neuroimage.2008; 39: 1824-1831.

[34]. During MJ, Cao L, Zuzga DS, et al. Glucagon-like peptide-1 receptor is involved in learning and neuroprotection. Nat Med. 2003; 9: 11731179.

[35]. Perry T, Haughey NJ, Mattson MP, Egan JM, Greig NH. Protection and reversal of excitotoxic neuronal damage by glucagon like peptide-1 and exendin-4. J Pharmacol Exp Ther.2002; 302: 881-888. 